\title{
Evaluation of the therapeutic educational consultations of patients infected by the Human Immunodeficiency Virus (HIV)
}

\author{
Jennifer Grangé*, Frederique Plassart, Philippe Genet, Tahar Touahri, Jean-Michel Descoutures \\ From $16^{\text {th }}$ International Symposium on HIV and Emerging Infectious Diseases \\ Marseille, France. 24-26 March 2010
}

\section{Background}

The objective of this survey is to evaluate the satisfaction and feeling of HIV infected patients following weekly therapeutic educational consultations in the hematology department (Argenteuil hospital).

\section{Methods}

Consultations are managed by a pharmacist who receives patients individually (initiation of treatment, side effects, non-compliance). A survey was carried out by a junior pharmacist. It includes 15 items on which the patient gives his opinion. The questionnaire was validated and presented to the patients. All patients had at least 2 therapeutic educational consultations implemented the survey.

\section{Results}

24 patients filled in the questionnaire over a 3 month period. $50 \%$ of them come from sub Saharan Africa.

Factors of improvement:

$\mathbb{\$}$ concerning the disease: Non-acceptance of the disease: $16,6 \%$; non-understanding of the disease: $12,5 \%$; non-understanding of the explanations on the viral reproduction: 20,9\%; information does not fit to their expectations: $8,3 \%$.

$\mathbb{S}$ concerning the treatment (explanations, information, observance, motivation), evaluation and listening: no discord.

$\mathbb{\$}$ concerning the progress of consultations (rythm, the duration of waiting...), more than $90 \%$ of patients are satisfied.

\section{Discussion}

An implementation of corrective measures is necessary:

$\mathbb{\$}$ to deal with the disease: to define clear objectives with the patients. A consultation with the psychologist must be proposed to all patients (multidisciplinary approach); the difficulties to understand the French language shows how our tools are not good enough or our vocabulary not adapted. It is necessary to develop an interactive process: creation of symptoms cards/decisions with pictures.

This survey shows that patients are satisfied with the consultations and underlines the importance to evaluate the need for modifying our professional practices.

Published: 11 May 2010

doi:10.1186/1742-4690-7-S1-P78

Cite this article as: Grangé et al: Evaluation of the therapeutic educational consultations of patients infected by the Human Immunodeficiency Virus (HIV). Retrovirology 2010 7(Suppl 1):P78.

Submit your next manuscript to BioMed Central and take full advantage of:

- Convenient online submission

- Thorough peer review

- No space constraints or color figure charges

- Immediate publication on acceptance

- Inclusion in PubMed, CAS, Scopus and Google Scholar

- Research which is freely available for redistribution

Submit your manuscript at www.biomedcentral.com/submit
C Biomed Central * Correspondence: jennifer.grange07@gmail.com
Victor Dupouy Hospital, Argenteuil, France 